\title{
Dual-sensitive HRE/Egr1 promoter regulates Smac overexpression and enhances radiation-induced A549 human lung adenocarcinoma cell death under hypoxia
}

\author{
CHANG-FENG LI, LI-BO CHEN, DAN-DAN LI, LEI YANG, BAO-GANG ZHANG, \\ JING-PENG JIN, YING ZHANG and BIN ZHANG \\ Endoscopy Center, China-Japan Union Hospital of Jilin University, Changchun, Jilin 130033, P.R. China
}

Received August 15, 2013; Accepted April 4, 2014

DOI: $10.3892 / \mathrm{mmr} .2014 .2233$

\begin{abstract}
The aim of this study was to construct an expression vector carrying the hypoxia/radiation dual-sensitive chimeric hypoxia response element (HRE)/early growth response 1 (Egr-1) promoter in order to overexpress the therapeutic second mitochondria-derived activator of caspases (Smac). Using this expression vector, the present study aimed to explore the molecular mechanism underlying radiotherapy-induced A549 human lung adenocarcinoma cell death and apoptosis under hypoxia. The plasmids, pcDNA3.1-Egrl-Smac (pE-Smac) and pcDNA3.1-HRE/Egr-1-Smac (pH/E-Smac), were constructed and transfected into A549 human lung adenocarcinoma cells using the liposome method. $\mathrm{CoCl}_{2}$ was used to chemically simulate hypoxia, followed by the administration of $2 \mathrm{~Gy} \mathrm{X}$-ray irradiation. An MTT assay was performed to detect cell proliferation and an Annexin V-fluorescein isothiocyanate apoptosis detection kit was used to detect apoptosis. Quantitative polymerase chain reaction and western blot analyses were used for the detection of mRNA and protein expression, respectively. Infection with the $\mathrm{pE}-\mathrm{Smac}$ and $\mathrm{pH} / \mathrm{E}-\mathrm{Smac}$ plasmids in combination with radiation and/or hypoxia was observed to enhance the expression of Smac. Furthermore, Smac overexpression was found to enhance the radiation-induced inhibition of cell proliferation and promotion of cycle arrest and apoptosis. The cytochrome $c /$ caspase-9/caspase-3 pathway was identified to be involved in this regulation of apoptosis. Plasmid infection in combination with X-ray irradiation was found to markedly induce cell death under hypoxia. In conclusion, the hypoxia/radiation dual-sensitive chimeric HRE/Egr-1 promoter was observed to enhance the expression of the therapeutic Smac, as well as enhance the radiation-induced
\end{abstract}

Correspondence to: Dr Bin Zhang, Endoscopy Center, China-Japan Union Hospital, Jilin University, 126 Xiantai Street, Changchun, Jilin 130033, P.R. China

E-mail: zrlgaozl@sina.com

Key words: hypoxia, radiation, Smac, lung adenocarcinoma, apoptosis, chimeric promoter inhibition of cell proliferation and promotion of cycle arrest and apoptosis under hypoxia. This apoptosis was found to involve the mitochondrial pathway.

\section{Introduction}

Radiotherapy is frequently used for the clinical treatment of lung cancer; however, its effectiveness is often impaired by radiation resistance (1). Combining gene therapy with radiotherapy, known as gene-radiotherapy, is a novel method for cancer treatment, and has attracted particular interest $(2,3)$. At present, gene-radiotherapy focuses on the radiation-inducible early growth response 1 (Egr1) promoter. This promoter contains six serum response elements, CC(A+T-rich)6GG motifs, which are sensitive to ionizing radiation $(4,5)$. Numerous studies have demonstrated that, under irradiation, the Egrl promoter is capable of regulating the overexpression of downstream genes, including TNF- $\alpha$, IFN- $\gamma$, endostatin and TRAIL (6-8).

Solid tumor hypoxia occurs when the growth rate of the tumor cells exceeds that of the tumor blood vessels, resulting in insufficient tumor blood supply. Hypoxic tumor cells account for between 10 and $50 \%$ of the cells in a solid tumor and cause radio- and chemotherapy resistance, leading to local tumor recurrence and distant metastasis (9). Hypoxic tumor cells have unique biological features that confer radioresistance and make tumor cells more aggressive. Under hypoxia, certain protective stress proteins are upregulated in tumor cells, including hypoxia-inducible factor- 1 , which specifically binds to hypoxia response elements (HREs), inducing the expression of downstream genes. HRE is a hypoxic enhancer with a core sequence of $5^{\prime}-(\mathrm{A} / \mathrm{G}) \mathrm{COT}(\mathrm{G} / \mathrm{C})(\mathrm{G} / \mathrm{C})-3^{\prime}$. Previous studies have shown that placing the HRE sequence upstream of the AFP, KDR, CMV and SV40 promoters, to constitute the chimeric promoters, markedly increases their transcriptional activities under hypoxia (10-12). Furthermore, placing the HRE sequence upstream of the Egr1 promoter has been found to enhance the radiation-induced overexpression of therapeutic genes in hypoxic tumor cells (13).

Ionizing radiation is capable of inducing tumor cell apoptosis and cell cycle arrest. Following cell cycle arrest, ionizing radiation-induced DNA damage is repaired, with 
cells undergoing apoptosis if repair cannot be completed (14). Pro-apoptotic genes can be used as targets in gene-radiotherapy. Therefore, hypoxia/radiation dual-sensitive HRE/Egr-1 promoter-mediated gene-radiotherapy may enhance hypoxic tumor cell apoptosis, increasing cell death.

The second mitochondria-derived activator of caspases (Smac) is located in the mitochondria and is released into the cytosol to exert its pro-apoptotic activity. Smac specifically binds to anti-apoptotic proteins, abolishing the suppression of the pro-apoptotic proteins caspase- 9 and -3 , which have a key role in cell apoptosis. Furthermore, Smac is capable of exerting direct pro-apoptotic effects by binding to apoptotic protease activating factor-1, cytochrome $c$ (Cyt $c$ ) and casapse-9 $(15,16)$. The overexpression of Smac has also been utilized for cancer treatment $(17,18)$.

The aim of the present study was to investigate the molecular mechanisms underlying radiation-induced A549 cell death upon the induction of hypoxia and the overexpression of Smac. A human Smac expression vector, pcDNA3.1-HRE/Egr-1-Smac (pH/E-Smac), containing the double-sensitive HRE/Egrl promoter, was constructed. The effect of Smac overexpression on the inhibition of cell proliferation and the promotion of cell cycle arrest and apoptosis was then assessed in A549 human lung adenocarcinoma cells subjected to hypoxia and 2 Gy X-ray irradiation.

\section{Materials and methods}

Cell line. A549 human lung adenocarcinoma cells were purchased from Peking Union Medical College Cell Bank (Beijing, China) and were cultured in high-glucose Dulbecco's Modified Eagle's Medium (Sigma-Aldrich, St. Louis, MO, USA) containing 10\% fetal bovine serum (FBS; Gibco-BRL, Grand Island, NY, USA) and $100 \mathrm{U} / \mathrm{ml}$ penicillin and streptomycin (Gibco-BRL) at $37^{\circ} \mathrm{C}$ in $5 \% \mathrm{CO}_{2}$. A549 cells were grown to $80 \%$ confluence in six-, 24- or 96 -well culture plates prior to treatment.

Plasmids. The plasmids pcDNA3.1-Egr1-TRAIL and pcDNA3.1-HRE-Egr1-TRAIL were obtained from Dr Yanming Yang (Jilin University, Changchun, China). The pcDNA3.1-CMV-Smac plasmid was constructed as described previously (19) and obtained from Dr Caixia Guo (Jilin University). Plasmids were digested using HindIII and BamHI, and the vector backbones and Smac fragments were subsequently recycled and ligated using the T4 DNA ligase to obtain the recombinant pcDNA3.1-Egr1-Smac (pE-Smac) and $\mathrm{pH} / \mathrm{E}-\mathrm{Smac}$ plasmids. Plasmids were identified using sequencing and restriction digestion.

Cell transfection, hypoxia simulation and $X$-ray irradiation. A549 cells were transfected using the Lipofectamine 2000 reagent (Invitrogen Life Technologies, Carlsbad, CA, USA) according to the manufacturer's instructions. Cells were cultured at $37^{\circ} \mathrm{C}$ in $5 \% \mathrm{CO}_{2}$ for a further $6 \mathrm{~h}$ with fresh medium containing $10 \%$ FBS. Twenty-four hours after transfection, $\mathrm{CoCl}_{2}$ (Sigma-Aldrich) was added at a final concentration of $150 \mu \mathrm{mol} / 1$ to simulate hypoxia, as described previously (20). $\mathrm{X}$-ray irradiation was then performed $24 \mathrm{~h}$ subsequent to the addition of $\mathrm{CoCl}_{2}$, using the Philips Deep Therapy machine at
$200 \mathrm{kV}$ and $10 \mathrm{~mA}$, using $0.5-\mathrm{mm} \mathrm{Cu}$ and $1-\mathrm{mm} \mathrm{Al}$ plates at $50 \mathrm{~cm}$ skin distance. A dose of $2 \mathrm{~Gy}$ was delivered at a rate of $0.287 \mathrm{~Gy} / \mathrm{min}$. The dose and dose rate were selected using the 1986 report from the United Nation Scientific Committee on the Effects of Atomic Radiation $(8,21,22)$.

MTT assay to detect cell proliferation. A549 cells were divided into six groups: Control, $\mathrm{pE}-\mathrm{Smac}, \mathrm{pH} / \mathrm{E}-\mathrm{Smac}, 2 \mathrm{~Gy}$, $\mathrm{pE}-\mathrm{Smac}+2 \mathrm{~Gy}$ and $\mathrm{pH} / \mathrm{E}-\mathrm{Smac}+2 \mathrm{~Gy}$. Briefly, A549 cells were seeded on 96 -well plates at $2 \times 10^{4}$ cells/well, with six replicates for each treatment. After $12 \mathrm{~h}$, transfection was performed. Twenty-four hours after transfection, cells were cultured in normoxic and hypoxic conditions simulated by the addition of $\mathrm{CoCl}_{2}$. After 24 h, 0 or 2 Gy X-ray radiation was administered. A total of $10 \mu \mathrm{l}$ MTT (Sigma-Aldrich) was added 0, $4,12,24$ and $48 \mathrm{~h}$ after irradiation, to form a final concentration of $5 \mathrm{mg} / \mathrm{ml}$. Following $4 \mathrm{~h}$ of incubation, the supernatant was discarded and $100 \mu \mathrm{l}$ dimethylsulfoxide (Sigma-Aldrich) was added to dissolve the crystals. The absorbance (A) value was measured at $570 \mathrm{~nm}$ using a microplate reader (Bio Rad, Hercules, CA, USA) (8). The experiment was repeated three times.

Flow cytometry (FCM) for the analysis of the cell cycle and apoptosis. FCM (Becton Dickinson Co., Franklin Lakes, NJ, USA) was performed to detect cell cycle arrest and apoptosis using propidium iodide (PI; Sigma-Aldrich) and the Annexin V-fluorescein isothiocyanate (FITC) double-staining kit (Nanjing KGI Biological Technology Development Co., Ltd., Nanjing, China). Briefly, A549 cells were seeded on 24-well plates at $3 \times 10^{5}$ cells/well and subjected to transfection, hypoxia simulation and irradiation according to the aforementioned methods. Twenty-four hours after irradiation, cells were collected in glass centrifuge tubes and washed twice with phosphate-buffered saline (PBS). The supernatant was discarded. To detect cell cycle phase, $50 \mu \mathrm{l}$ RNase A and $200 \mu \mathrm{l}$ PI were added and mixed in the dark at room temperature for $20 \mathrm{~min}$. To detect the cell apoptosis, cells were resuspended in $500 \mu \mathrm{l}$ PBS, and $5 \mu \mathrm{l}$ Annexin V-FITC and $5 \mu \mathrm{l}$ PI were added and mixed in the dark at room temperature for $15 \mathrm{~min}$. The cell samples were then assessed using FCM. The BD CellQuest ${ }^{\mathrm{TM}}$ (Becton Dickinson Co.) software was used to acquire and analyze the data.

Quantitative polymerase chain reaction ( $q P C R)$ analysis of $m R N A$ expression. A549 cells were seeded on six-well plates at $5 \times 10^{5}$ cells/well, prior to transfection, hypoxia simulation and irradiation as described above. Cells were collected $24 \mathrm{~h}$ after irradiation and total RNA was extracted using TRIzol ${ }^{\circledR}$ Reagent (Invitrogen Life Technologies) according to the manufacturer's instructions. The extracted RNA was quantified by detection of the $\mathrm{A}_{260} / \mathrm{A}_{280}$ ratio. cDNA was synthesized using a reverse transcription kit (MBI Fermentas Inc., Burlington, ON, Canada) according to the manufacturer's instructions (200 ng RNA, $20 \mu \mathrm{l}$ reaction system). The reaction conditions were $42^{\circ} \mathrm{C}$ for $60 \mathrm{~min}$, followed by $70^{\circ} \mathrm{C}$ for $2 \mathrm{~min}$. The PrimeScript ${ }^{\circledR}$ RT-PCR kit (Takara Bio, Inc., Dalian, China) and an Mx3000P ${ }^{\text {тм }}$ Real-Time PCR System (Stratagene, La Jolla, CA, USA) were used for the qPCR and the subsequent analysis of results. Primer3 software (23) was used to design 
the GAPDH, Smac, Cyt c, caspase- 9 and -3 primers, which were synthesized by Takara Bio, Inc. and are shown in Table I. The reaction conditions were as follows: $95^{\circ} \mathrm{C}$ for $30 \mathrm{sec}$, one cycle; $95^{\circ} \mathrm{C}$ for $20 \mathrm{sec}$ and $60^{\circ} \mathrm{C}$ for $20 \mathrm{sec}, 40$ cycles; $95^{\circ} \mathrm{C}$ for $1 \mathrm{~min}$, one cycle; $55^{\circ} \mathrm{C}$ for $30 \mathrm{sec}$ and $95^{\circ} \mathrm{C}$ for $30 \mathrm{sec}$. Relative mRNA expression was calculated as the ratio of the gene of interest mRNA/GAPDH mRNA.

Western blot analysis to detect protein expression. A549 cells were seeded on six-well plates at $1 \times 10^{6}$ cells/well, and subjected to transfection, hypoxia simulation and irradiation according to the aforementioned methods. Cells were collected $24 \mathrm{~h}$ after irradiation, and lysis buffer $(10 \mathrm{mmol} / \mathrm{l}$ Tris- $\mathrm{HCl}$, $\mathrm{pH} 7.4 ; 1 \mathrm{mmol} / \mathrm{l}$ EDTA, pH 8.0; $0.1 \mathrm{~mol} / \mathrm{l} \mathrm{NaCl} ; 1 \mu \mathrm{g} / \mathrm{ml}$ aprotinin; $100 \mu \mathrm{g} / \mathrm{ml}$ phenylmethanesulfonyl fluoride) was used to extract the total protein. The Coomassie Brilliant Blue protein quantification kit (Nanjing Jiancheng Bioengineering Institute, Nanjing, China) was used to quantify the total protein. Proteins were separated using 12\% SDS-PAGE with a sample loading of $50 \mu \mathrm{g} /$ lane. Proteins were then transferred to a nitrocellulose membrane. The membrane was blocked using $5 \%$ non-fat, dry milk for $1 \mathrm{~h}$, prior to incubation with primary antibodies against $\beta$-actin, Smac, Cyt c, caspase- 9 and -3 , respectively, overnight at $4^{\circ} \mathrm{C}$. Membranes were then washed twice using Tris-buffered saline containing 0.05\% Tween 20, prior to incubation with horseradish peroxidase-conjugated secondary antibodies at $37^{\circ} \mathrm{C}$ for $1 \mathrm{~h}$ (Pierce Biotechnology, Inc., Rockford, IL, USA). The enhanced chemical luminescence light system method (Santa Cruz Biotechnology Inc., Santa Cruz, CA, USA) was used to visualize the immunoreactive bands. Images were captured for analysis.

Statistical analysis. Experimental data are presented as the mean \pm standard deviation. Results were analyzed using one-way analysis of variance with the SPSS 12.0 statistical software (SPSS, Inc., Chicago, IL, USA). A value of $\mathrm{P}<0.05$ was considered to indicate a statistically significant difference.

\section{Results}

Sequencing and restriction digestion of $p E-S m a c$ and $p H / E$-Smac. The pE-Smac plasmid was digested by SmaI, $X b a \mathrm{I}$ and $X h o \mathrm{I}$ enzymes. The fragments generated were 2,292 and 3,772 bp (SmaI); 828 and 5,236 bp (XbaI) and 908 and 5,156 bp (XhoI) (Fig. 1A). The pH/E-Smac plasmid was digested using BamHI and SmaI enzymes. The digested fragments were 1,284 and 4,926 bp (BamHI) and 2,292 and 3,918 bp (SmaI) (Fig. 1B). All fragments were as expected, and sequencing revealed that fragment sequences were consistent with those expected (data not shown).

A549 cell proliferation. The results of the MTT assay used to assess A549 cell proliferation are shown in Table II. Under normoxic conditions, no significant differences were observed in A549 cell proliferation among the control, pE-Smac and $\mathrm{pH} / \mathrm{E}$-Smac groups $(\mathrm{P}>0.05)$. However, a significant decrease in A549 cell proliferation was observed in the $2 \mathrm{~Gy}(\mathrm{P}<0.05)$, $\mathrm{pE}-\mathrm{Smac}+2 \mathrm{~Gy}$ and $\mathrm{pH} / \mathrm{E}-\mathrm{Smac}+2$ Gy groups (both $\mathrm{P}<0.001$ ), compared with the control group at each time-point. Compared with normoxia, hypoxic treatment was found to significantly
Table I. Primer sequences.

\begin{tabular}{ll}
\hline Gene & \multicolumn{1}{c}{ Sequence } \\
\hline GAPDH & \\
Sense & 5'-ACCACAGTCCATGCCATCAC-3' \\
Antisense & 5'-TCCACCACCCTGTTGCTGTA-3' \\
Smac & \\
Sense & 5'-CTGTCGCGCAGCGTAACTTC-3' \\
Antisense & 5'-GGTTACTCCAAAGCCAATCGTCA-3' \\
Cyt $c$ & \\
Sense & 5'-GGGCGAGAGCTATGTAATGCAAG-3' \\
Antisense & 5'-TACAGCCAAAGCAGCAGCTCA-3' \\
Caspase-9 & \\
Sense & 5'-GGACATCCAGCGGGCAGG-3' \\
Antisense & 5'-TCTAAGCAGGAGATGAACAAAGG-3' \\
Caspase-3 & \\
Sense & 5'-TTCAGGCCTGCCGTGGTACA-3' \\
Antisense & 5'-CCAAGAATAATAACCAGGTGCT-3' \\
\hline
\end{tabular}

Smac, second mitochondria-derived activator of caspases; Cyt $c$, cytochrome $c$.

reduce A549 cell proliferation $(\mathrm{P}<0.05$ or $\mathrm{P}<0.001)$, particularly in the $\mathrm{pH} / \mathrm{E}-\mathrm{Smac}+2$ Gy group $(\mathrm{P}<0.001)$.

A549 cell cycle phase. Table III and Fig. 2 show A549 cell cycle phase under normoxia and hypoxia, detected using FCM with PI staining. Under normoxia, in the $2 \mathrm{~Gy}, \mathrm{pE}-\mathrm{Smac}+2 \mathrm{~Gy}$ and $\mathrm{pH} / \mathrm{E}-\mathrm{Smac}+2 \mathrm{~Gy}$ groups, the proportion of cells in S phase was significantly decreased compared with the control, while the proportion of cells in $\mathrm{G}_{2} / \mathrm{M}$ phase was significantly increased compared with the control $(\mathrm{P}<0.05)$. No significant differences were observed in the other treatment groups under normoxia. Under hypoxia, in the pH/E-Smac, 2 Gy, pE-Smac+2 Gy and $\mathrm{pH} / \mathrm{E}-\mathrm{Smac}+2 \mathrm{~Gy}$ groups, the proportion of cells in the $\mathrm{G}_{0} / \mathrm{G}_{1}$ and $\mathrm{G}_{2} / \mathrm{M}$ phases was observed to be significantly increased compared with the control, while the proportion in $\mathrm{S}$ phase was found to be significantly reduced $(\mathrm{P}<0.05$ or $\mathrm{P}<0.001)$. With the exception of the $\mathrm{G}_{2} / \mathrm{M}$ phase in the control and $\mathrm{pE}-\mathrm{Smac}$ groups, the changes in the percentage of cells in $\mathrm{G}_{0} / \mathrm{G}_{1}, \mathrm{~S}$ and $\mathrm{G}_{2} / \mathrm{M}$ phases under hypoxia were significantly greater than those under normoxia $(\mathrm{P}<0.05$ or $\mathrm{P}<0.001)$. These findings suggest that 2 Gy $\mathrm{X}$-ray irradiation can induce $\mathrm{G}_{2} / \mathrm{M}$-phase arrest and that hypoxia induces $\mathrm{G}_{0} / \mathrm{G}_{1}$ arrest. The greatest cell cycle arrest was achieved in the $\mathrm{pH} / \mathrm{E}-\mathrm{Smac}+2 \mathrm{~Gy}$ group under hypoxia.

A549 cell apoptosis. Table IV and Fig. 3 show the results of the FCM used to detect A549 cell apoptosis under normoxia and hypoxia. Under normoxia, the percentage of apoptotic A549 cells in the $2 \mathrm{~Gy}, \mathrm{pE}-\mathrm{Smac}+2 \mathrm{~Gy}$ and $\mathrm{pH} / \mathrm{E}-\mathrm{Smac}+2 \mathrm{~Gy}$ groups was observed to be significantly increased compared with that in the control group $(\mathrm{P}<0.05$ or $\mathrm{P}<0.01)$, particularly in the $\mathrm{pE}-\mathrm{Smac}+2 \mathrm{~Gy}$ and $\mathrm{pH} / \mathrm{E}-\mathrm{Smac}+2 \mathrm{~Gy}$ groups. No significant difference was observed between the $\mathrm{pE}-\mathrm{Smac}+2 \mathrm{~Gy}$ and $\mathrm{pH} / \mathrm{E}-\mathrm{Smac}+2 \mathrm{~Gy}$ groups. Under hypoxia, the percentage of 
Table II. Absorbance value of A549 cells under normoxia and hypoxia.

\begin{tabular}{lccccc}
\hline & \multicolumn{5}{c}{ Time (h) } \\
\cline { 2 - 6 } Groups & 0 & 4 & 12 & 24 & 48 \\
\hline Normoxia & & & & \\
Control & $0.416 \pm 0.002$ & $0.423 \pm 0.008$ & $0.489 \pm 0.023$ & $0.665 \pm 0.058$ & $0.787 \pm 0.035$ \\
pE-Smac & $0.424 \pm 0.008$ & $0.415 \pm 0.011$ & $0.490 \pm 0.021$ & $0.663 \pm 0.017$ & $0.758 \pm 0.060$ \\
pH/E-Smac & $0.414 \pm 0.016$ & $0.414 \pm 0.005$ & $0.452 \pm 0.027$ & $0.628 \pm 0.056$ & $0.775 \pm 0.037$ \\
2 Gy & $0.432 \pm 0.010^{\mathrm{a}}$ & $0.410 \pm 0.003^{\mathrm{a}}$ & $0.421 \pm 0.003^{\mathrm{a}}$ & $0.431 \pm 0.004^{\mathrm{a}}$ & $0.469 \pm 0.009^{\mathrm{b}}$ \\
pE-Smac+2 Gy & $0.435 \pm 0.011^{\mathrm{a}}$ & $0.385 \pm 0.006^{\mathrm{b}}$ & $0.361 \pm 0.012^{\mathrm{b}}$ & $0.367 \pm 0.008^{\mathrm{a}}$ & $0.381 \pm 0.005^{\mathrm{b}}$ \\
pH/E-Smac+2 Gy & $0.442 \pm 0.013^{\mathrm{a}}$ & $0.381 \pm 0.009^{\mathrm{b}}$ & $0.361 \pm 0.009^{\mathrm{b}}$ & $0.368 \pm 0.014^{\mathrm{b}}$ & $0.378 \pm 0.021^{\mathrm{b}}$ \\
Hypoxia & & & & & \\
Control & $0.383 \pm 0.050$ & $0.419 \pm 0.018$ & $0.387 \pm 0.009^{\mathrm{c}}$ & $0.460 \pm 0.041^{\mathrm{c}}$ & $0.495 \pm 0.034^{\mathrm{d}}$ \\
pE-Smac & $0.402 \pm 0.011^{\mathrm{c}}$ & $0.412 \pm 0.010$ & $0.393 \pm 0.005^{\mathrm{c}}$ & $0.485 \pm 0.023^{\mathrm{d}}$ & $0.459 \pm 0.028^{\mathrm{c}}$ \\
pH/E-Smac & $0.347 \pm 0.008^{\mathrm{d}}$ & $0.339 \pm 0.006^{\mathrm{b}, \mathrm{d}}$ & $0.385 \pm 0.007^{\mathrm{a}, \mathrm{c}}$ & $0.424 \pm 0.008^{\mathrm{c}}$ & $0.422 \pm 0.009^{\mathrm{a}, \mathrm{d}}$ \\
2 Gy & $0.408 \pm 0.006^{\mathrm{c}}$ & $0.399 \pm 0.007$ & $0.353 \pm 0.015^{\mathrm{b}, \mathrm{c}}$ & $0.397 \pm 0.010^{\mathrm{c}}$ & $0.410 \pm 0.009^{\mathrm{a}, \mathrm{d}}$ \\
pE-Smac+2 Gy & $0.413 \pm 0.009^{\mathrm{d}}$ & $0.394 \pm 0.006^{\mathrm{b}}$ & $0.323 \pm 0.013^{\mathrm{b}, \mathrm{c}}$ & $0.343 \pm 0.006^{\mathrm{a}, \mathrm{c}}$ & $0.350 \pm 0.008^{\mathrm{a}, \mathrm{c}}$ \\
pH/E-Smac+2 Gy & $0.339 \pm 0.004^{\mathrm{c}}$ & $0.329 \pm 0.020^{\mathrm{c}}$ & $0.290 \pm 0.016^{\mathrm{d}}$ & $0.254 \pm 0.032^{\mathrm{b}, \mathrm{c}}$ & $0.153 \pm 0.026^{\mathrm{b}, \mathrm{d}}$ \\
\hline
\end{tabular}

Data are presented as the mean \pm standard deviation, $\mathrm{n}=6 .{ }^{\mathrm{a}} \mathrm{P}<0.05$ and ${ }^{\mathrm{b}} \mathrm{P}<0.001$ versus control group; ${ }^{\mathrm{c}} \mathrm{P}<0.05$ and ${ }^{\mathrm{d}} \mathrm{P}<0.001$ versus normoxia. pE-Smac, pcDNA3.1-Egr1-Smac; pH/E-Smac, pcDNA3.1-HRE/Egr1-Smac.

A

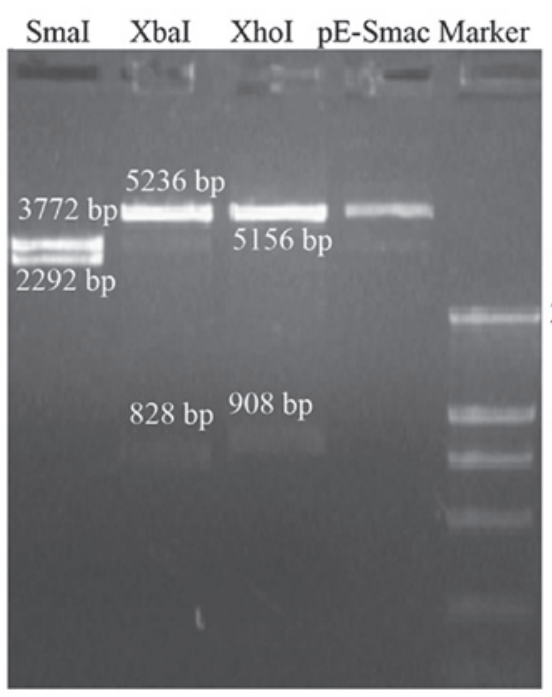

B

BamHI SmaI pH/E-Smac Marker

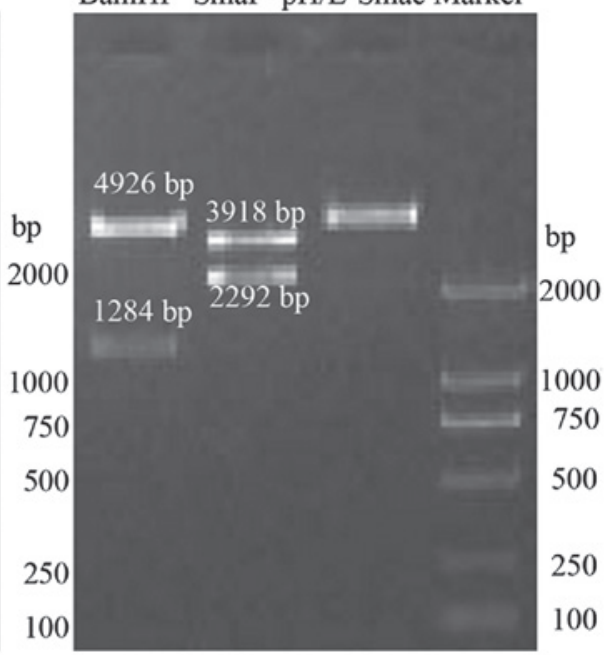

Figure 1. Identification of(A) pE-Smacand(B) pH/E-Smacusing restriction digestion.pE-Smac,pcDNA3.1-Egr1-Smac;pH/E-Smac,pcDNA3.1-HRE/Egr1-Smac.

apoptotic A549 cells in the pH/E-Smac, 2 Gy, pE-Smac+2 Gy and $\mathrm{pH} / \mathrm{E}-\mathrm{Smac}+2 \mathrm{~Gy}$ groups was increased significantly compared with that in the control group $(\mathrm{P}<0.05$ or $\mathrm{P}<0.01)$, particularly in the $\mathrm{pH} / \mathrm{E}-\mathrm{Smac}+2$ Gy group. Furthermore, the percentage of apoptotic cells in each hypoxic group was found to be increased significantly compared with each normoxic group $(\mathrm{P}<0.05$ or $\mathrm{P}<0.01)$.

Smac, Cyt c and caspase-9 and -3 mRNA expression in A549 cells. qPCR analysis was performed to detect Smac, Cyt $c$, and caspase- 9 and -3 mRNA expression. The relative mRNA levels were calculated as the ratio of experimental/control mRNA expression, as shown in Table V. With the exception of Cyt $c$ expression in the 2 Gy group, under normoxia Smac, Cyt $c$, and caspase- 9 and -3 mRNA levels in the $2 \mathrm{~Gy}, \mathrm{pE}-\mathrm{Smac}+2 \mathrm{~Gy}$ and $\mathrm{pH} / \mathrm{E}-\mathrm{Smac}+2 \mathrm{~Gy}$ groups were significantly increased compared with those in the control group $(\mathrm{P}<0.05$ or $\mathrm{P}<0.01)$, with no significant difference observed in the mRNA expression between the $\mathrm{pE}-\mathrm{Smac}+2 \mathrm{~Gy}$ and $\mathrm{pH} / \mathrm{E}-\mathrm{Smac}+2 \mathrm{~Gy}$ groups. With the exception of Cyt $c$ and caspase-3 in the $\mathrm{pH} / \mathrm{E}-\mathrm{Smac}$ group, the mRNA levels of Smac, Cyt $c$, and caspase- 9 and -3 in the pH/E-Smac, 2 Gy, pE-Smac+2 Gy and $\mathrm{pH} / \mathrm{E}-\mathrm{Smac}+2 \mathrm{~Gy}$ groups under hypoxia were found to be significantly increased compared with those in the control 
Table III. Percentage of A549 cells in each cell cycle phase under normoxia and hypoxia.

\begin{tabular}{lccc}
\hline & \multicolumn{3}{c}{ Cell percentage $(\%)$} \\
\cline { 2 - 4 } Groups & $\mathrm{G}_{0} / \mathrm{G}_{1}$ & $\mathrm{~S}$ & $\mathrm{G}_{2} / \mathrm{M}$ \\
\hline Normoxia & & & $3.13 \pm 1.18$ \\
Control & $54.17 \pm 1.59$ & $42.69 \pm 4.55$ & $3.45 \pm 0.49$ \\
pE-Smac & $53.78 \pm 0.69$ & $42.77 \pm 0.53$ & $2.86 \pm 0.68$ \\
pH/E-Smac & $54.04 \pm 2.34$ & $39.44 \pm 1.99$ & $6.53 \pm 0.21^{\mathrm{a}}$ \\
2 Gy & $61.55 \pm 1.42$ & $31.92 \pm 1.23^{\mathrm{a}}$ & $6.23 \pm 0.89^{\mathrm{a}}$ \\
pE-Smac+2 Gy & $61.85 \pm 2.33$ & $31.95 \pm 1.51^{\mathrm{a}}$ & $6.20 \pm 0.26^{\mathrm{a}}$ \\
pH/E-Smac+2 Gy & $60.89 \pm 2.09$ & $32.91 \pm 1.86^{\mathrm{a}}$ & \\
Hypoxia & & & $3.13 \pm 0.21$ \\
Control & $65.47 \pm 0.62^{\mathrm{b}}$ & $31.40 \pm 0.60^{\mathrm{b}}$ & $3.54 \pm 0.92$ \\
pE-Smac & $65.55 \pm 1.48^{\mathrm{b}}$ & $30.91 \pm 1.66^{\mathrm{c}}$ & $17.49 \pm 1.21^{\mathrm{a}, \mathrm{c}}$ \\
pH/E-Smac & $70.72 \pm 0.86^{\mathrm{a}, \mathrm{b}}$ & $11.79 \pm 1.33^{\mathrm{c}, \mathrm{d}}$ & $17.67 \pm 0.53^{\mathrm{c}, \mathrm{d}}$ \\
2 Gy & $71.51 \pm 0.89^{\mathrm{a}, \mathrm{b}}$ & $10.82 \pm 1.26^{\mathrm{c}, \mathrm{d}}$ & $21.41 \pm 0.62^{\mathrm{c}, \mathrm{d}}$ \\
pE-Smac+2 Gy & $71.74 \pm 1.20^{\mathrm{a}, \mathrm{b}}$ & $6.85 \pm 1.29^{\mathrm{c}, \mathrm{d}}$ & $22.15 \pm 1.29^{\mathrm{a}, \mathrm{b}}$ \\
pH/E-Smac+2 Gy & $70.74 \pm 0.27^{\mathrm{a}, \mathrm{b}}$ & $7.12 \pm 1.54^{\mathrm{c}, \mathrm{d}}$ & \\
\hline
\end{tabular}

Data are presented as the mean \pm standard deviation, $n=3$. ${ }^{a} \mathrm{P}<0.05$ and ${ }^{\mathrm{d}} \mathrm{P}<0.01$ versus control group; ${ }^{\mathrm{b}} \mathrm{P}<0.05$ and ${ }^{\mathrm{c}} \mathrm{P}<0.001$ versus normoxia. pE-Smac, pcDNA3.1-Egr1-Smac; pH/E-Smac, pcDNA3.1-HRE/Egr1-Smac.

group $(\mathrm{P}<0.05$ or $\mathrm{P}<0.001)$, particularly in the $\mathrm{pH} / \mathrm{E}-\mathrm{Smac}+2$ Gy group. Overall, with the exception of Cyt $c$ in the control, $\mathrm{pE}-\mathrm{Smac}$ and $\mathrm{pE}-\mathrm{Smac}+2 \mathrm{~Gy}$ groups, hypoxia was found to significantly increase Smac, Cyt $c$, caspase-9 and -3 mRNA levels compared with normoxia $(\mathrm{P}<0.05$ or $\mathrm{P}<0.001)$.

Smac, Cyt c, casapase-9 and -3 protein expression in A549 cells. As shown in Fig. 4, western blot analysis was used to detect Smac, Cyt $c$, and caspase- 9 and -3 protein expression. Under normoxia, the expression of the housekeeping protein $\beta$-actin (molecular weight, $42 \mathrm{kDa}$ ) was consistent in each group. The protein expression of Smac $(25 \mathrm{kDa})$ and Cyt c (12 kDa) was observed to increase in the $2 \mathrm{~Gy}, \mathrm{pE}-\mathrm{Smac}+2 \mathrm{~Gy}$ and $\mathrm{pH} / \mathrm{E}-\mathrm{Smac}+2$ Gy groups, while that of the caspase-9 and -3 precursors ( $42 \mathrm{kDa}$ and $27 \mathrm{kDa}$, respectively) were consistent among all six groups. Expression of the activated caspase- 9 protein $(35 \mathrm{kDa})$ was observed to increase in the 2 Gy, pE-Smac+2 Gy and pH/E-Smac+2 Gy groups, and that of the activated caspase-3 protein $(21 \mathrm{kDa})$ was found to increase in the $\mathrm{pE}-\mathrm{Smac}+2 \mathrm{~Gy}$ and $\mathrm{pH} / \mathrm{E}-\mathrm{Smac}+2 \mathrm{~Gy}$ groups.

Under hypoxia, expression of the housekeeping protein $\beta$-actin was consistent in each group. However, the protein expression of Smac and Cyt $c$ was observed to increase in the $\mathrm{pH} / \mathrm{E}-\mathrm{Smac}, 2 \mathrm{~Gy}, \mathrm{pE}-\mathrm{Smac}+2 \mathrm{~Gy}$ and $\mathrm{pH} / \mathrm{E}-\mathrm{Smac}+2 \mathrm{~Gy}$ groups, with the highest expression observed in the $\mathrm{pH} / \mathrm{E}-\mathrm{Smac}+2 \mathrm{~Gy}$ group. The expression of the precursor and activated caspase- 9 proteins was found to increase under hypoxia, particularly in the pE-Smac+2 Gy and $\mathrm{pH} / \mathrm{E}-\mathrm{Smac}+2 \mathrm{~Gy}$ groups. No difference was observed in the expression of the caspase-3 precursor protein under hypoxia; however, the expression of the activated protein was found to increase in the $2 \mathrm{~Gy}, \mathrm{pE}-\mathrm{Smac}+2 \mathrm{~Gy}$ and $\mathrm{pH} / \mathrm{E}-\mathrm{Smac}+2 \mathrm{~Gy}$ groups, particularly in the $\mathrm{pH} / \mathrm{E}-\mathrm{Smac}+2 \mathrm{~Gy}$ group. When
Table IV. Percentage of apoptotic A549 cells under normoxia and hypoxia.

\begin{tabular}{llc}
\hline & \multicolumn{2}{c}{ Apoptotic percentage $(\%)$} \\
\cline { 2 - 3 } Groups & Normoxia & Hypoxia \\
\hline Control & $0.60 \pm 0.10$ & $2.90 \pm 0.20^{\mathrm{a}}$ \\
$\mathrm{pE}-$ Smac & $0.67 \pm 0.15$ & $2.53 \pm 0.47^{\mathrm{b}}$ \\
$\mathrm{pH} / \mathrm{E}-\mathrm{Smac}$ & $0.73 \pm 0.06$ & $5.07 \pm 0.15^{\mathrm{a}, \mathrm{c}}$ \\
2 Gy & $2.87 \pm 0.15^{\mathrm{c}}$ & $7.27 \pm 0.25^{\mathrm{a}, \mathrm{c}}$ \\
$\mathrm{pE}-$ Smac+2 Gy & $4.50 \pm 0.30^{\mathrm{d}}$ & $8.27 \pm 0.15^{\mathrm{a}, \mathrm{c}}$ \\
$\mathrm{pH} / \mathrm{E}-\mathrm{Smac}+2 \mathrm{~Gy}$ & $4.80 \pm 0.30^{\mathrm{d}}$ & $17.8 \pm 0.83^{\mathrm{b}, \mathrm{c}}$ \\
\hline
\end{tabular}

Data are presented as the mean \pm standard deviation, $n=3$. ${ }^{d} \mathrm{P}<0.05$ and ${ }^{\mathrm{c}} \mathrm{P}<0.01$ versus control group; ${ }^{\mathrm{b}} \mathrm{P}<0.05$ and ${ }^{\mathrm{a}} \mathrm{P}<0.001$ versus normoxia. pE-Smac, pcDNA3.1-Egr1-Smac; pH/E-Smac, pcDNA3.1-HRE/Egr1-Smac.

compared with normoxia, hypoxic treatment was found to increase the expression of the Smac, Cyt $\mathrm{c}$ and caspase-9 and -3 precursor and activated proteins.

\section{Discussion}

Cells in solid tumors cause a hypoxic microenvironment, which results in radiation resistance (24). Based on the hypoxia-inducible nature of the HRE promoter (10-12), the present study aimed to use the HRE promoter in lung cancer gene therapy to promote the downstream expression of the therapeutic Smac and increase the tumor cell death. Furthermore, the radiation-inducible Egr-1 promoter, which is activated 
Table V. Relative mRNA expression of Cyt c, caspase-9 and -3 in A549 cells under normoxia and hypoxia.

\begin{tabular}{|c|c|c|c|c|}
\hline \multirow[b]{2}{*}{ Groups } & \multicolumn{4}{|c|}{ Relative mRNA expression } \\
\hline & Smac & Cyt $c$ & Caspase-9 & Caspase-3 \\
\hline \multicolumn{5}{|l|}{ Normoxia } \\
\hline Control & 1 & 1 & 1 & 1 \\
\hline $\mathrm{pE}-\mathrm{Smac}$ & $1.09 \pm 0.05$ & $1.06 \pm 0.05$ & $1.03 \pm 0.03$ & $1.09 \pm 0.06$ \\
\hline $\mathrm{pH} / \mathrm{E}-\mathrm{Smac}$ & $1.09 \pm 0.06$ & $1.08 \pm 0.06$ & $1.06 \pm 0.06$ & $1.05 \pm 0.04$ \\
\hline 2 Gy & $4.42 \pm 0.51^{\mathrm{a}}$ & $1.73 \pm 0.32$ & $5.89 \pm 0.19^{\mathrm{a}}$ & $5.72 \pm 0.29^{\mathrm{a}}$ \\
\hline $\mathrm{pE}-\mathrm{Smac}+2 \mathrm{~Gy}$ & $20.51 \pm 1.67^{\mathrm{a}}$ & $7.22 \pm 0.27^{\mathrm{a}}$ & $5.76 \pm 0.10^{b}$ & $32.03 \pm 2.49^{\mathrm{a}}$ \\
\hline $\mathrm{pH} / \mathrm{E}-\mathrm{Smac}+2 \mathrm{~Gy}$ & $20.23 \pm 0.75^{\mathrm{a}}$ & $7.41 \pm 0.42^{\mathrm{a}}$ & $6.91 \pm 0.28^{\mathrm{a}}$ & $32.08 \pm 3.60^{\mathrm{a}}$ \\
\hline \multicolumn{5}{|l|}{ Hypoxia } \\
\hline Control & $2.82 \pm 0.13^{\mathrm{c}}$ & $1.23 \pm 0.10$ & $2.34 \pm 0.06^{c}$ & $3.06 \pm 0.16^{\mathrm{c}}$ \\
\hline pE-Smac & $2.75 \pm 0.09^{\mathrm{d}}$ & $1.27 \pm 0.15$ & $2.56 \pm 0.07^{\mathrm{d}}$ & $3.18 \pm 0.17^{\mathrm{c}}$ \\
\hline $\mathrm{pH} / \mathrm{E}-\mathrm{Smac}$ & $6.34 \pm 0.26^{\mathrm{b}, \mathrm{d}}$ & $1.20 \pm 0.04^{\mathrm{c}}$ & $6.04 \pm 0.13^{\mathrm{b}, \mathrm{d}}$ & $3.12 \pm 0.04^{\mathrm{d}}$ \\
\hline 2 Gy & $9.75 \pm 0.72^{\mathrm{a}, \mathrm{c}}$ & $2.83 \pm 0.34^{\mathrm{a}, \mathrm{c}}$ & $12.73 \pm 1.21^{\mathrm{a}, \mathrm{c}}$ & $11.14 \pm 0.23^{\mathrm{b}, \mathrm{d}}$ \\
\hline $\mathrm{pE}-\mathrm{Smac}+2 \mathrm{~Gy}$ & $10.66 \pm 0.68^{\mathrm{a}, \mathrm{c}}$ & $7.64 \pm 0.43^{\mathrm{a}}$ & $13.12 \pm 1.53^{\mathrm{a}, \mathrm{c}}$ & $41.82 \pm 1.57^{\mathrm{b}, \mathrm{c}}$ \\
\hline $\mathrm{pH} / \mathrm{E}-\mathrm{Smac}+2 \mathrm{~Gy}$ & $39.71 \pm 2.69^{a, c}$ & $16.8 \pm 0.80^{\mathrm{a}, \mathrm{d}}$ & $19.56 \pm 0.99^{\mathrm{a}, \mathrm{c}}$ & $59.09 \pm 1.59^{\mathrm{b}, \mathrm{d}}$ \\
\hline
\end{tabular}

Data are presented as the mean \pm standard deviation, $\mathrm{n}=3$. ${ }^{\mathrm{a}} \mathrm{P}<0.05$ and ${ }^{\mathrm{b}} \mathrm{P}<0.01$ versus control group; ${ }^{\mathrm{c}} \mathrm{P}<0.05$ and ${ }^{\mathrm{d}} \mathrm{P}<0.001$ versus normoxia. Smac, second mitochondria-derived activator of caspases; Cyt $c$, cytochrome $c$; pE-Smac, pcDNA3.1-Egr1-Smac; pH/E-Smac, pcDNA3.1-HRE/Egr1-Smac.

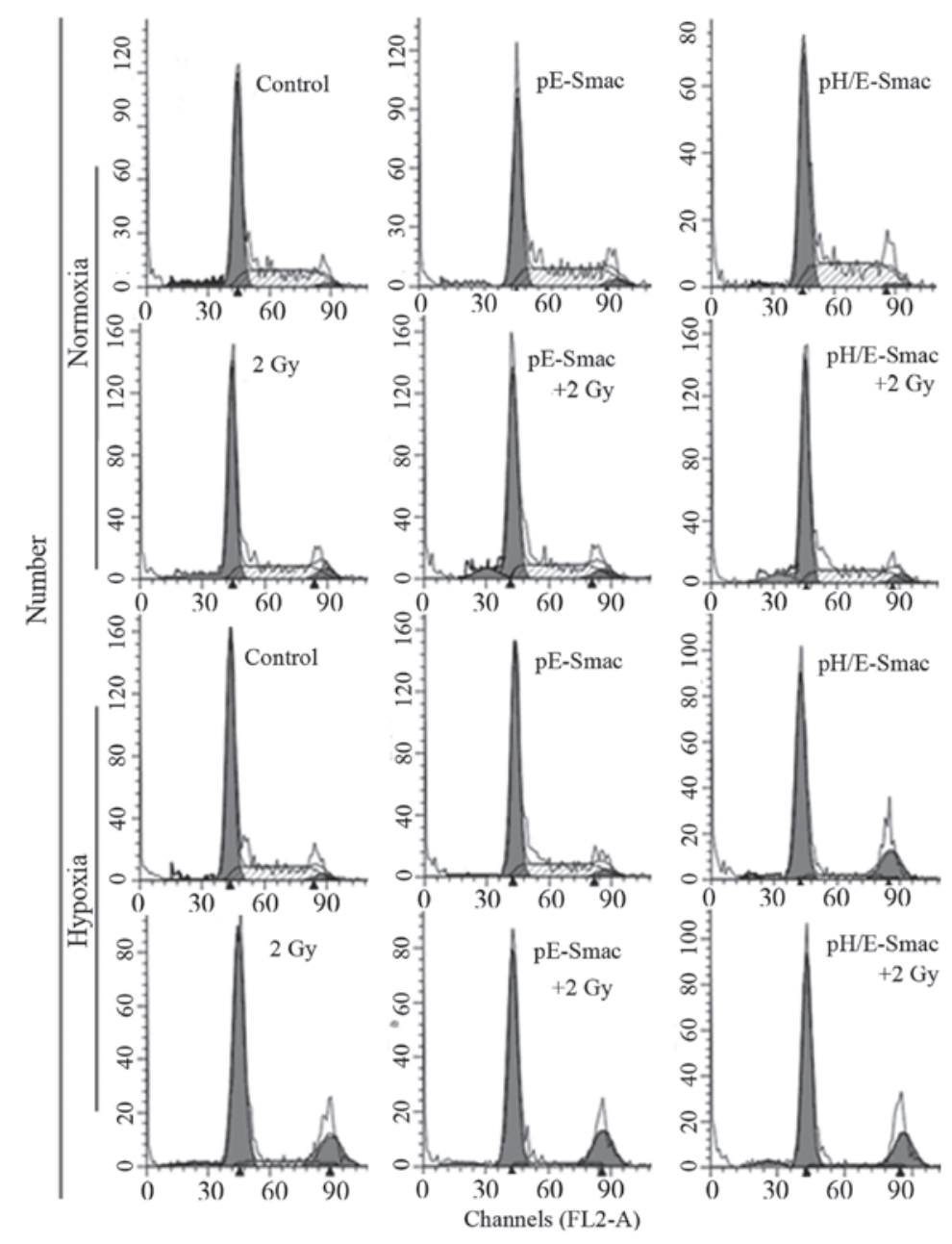

Figure 2. Percentage of A549 cells in each cycle phase, as determined by flow cytometry. pE-Smac, pcDNA3.1-Egr1-Smac; pH/E-Smac, pcDNA3.1-HRE/Egr1-Smac. 


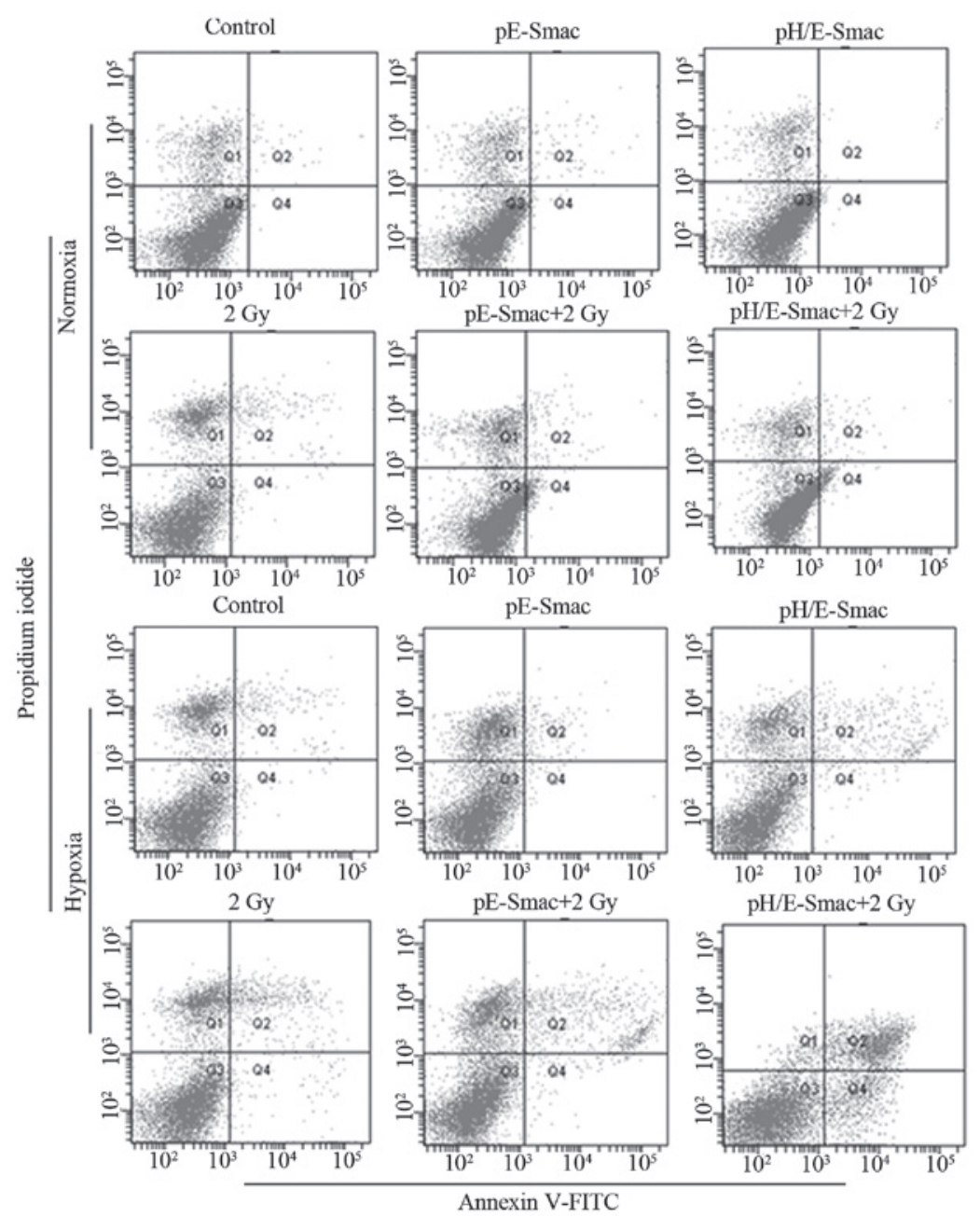

Figure 3. Percentage of apoptotic A549 cells, as determined by flow cytometry. FITC, fluorescein isothiocyanate; pE-Smac, pcDNA3.1-Egr1-Smac; pH/E-Smac, pcDNA3.1-HRE/Egr1-Smac.

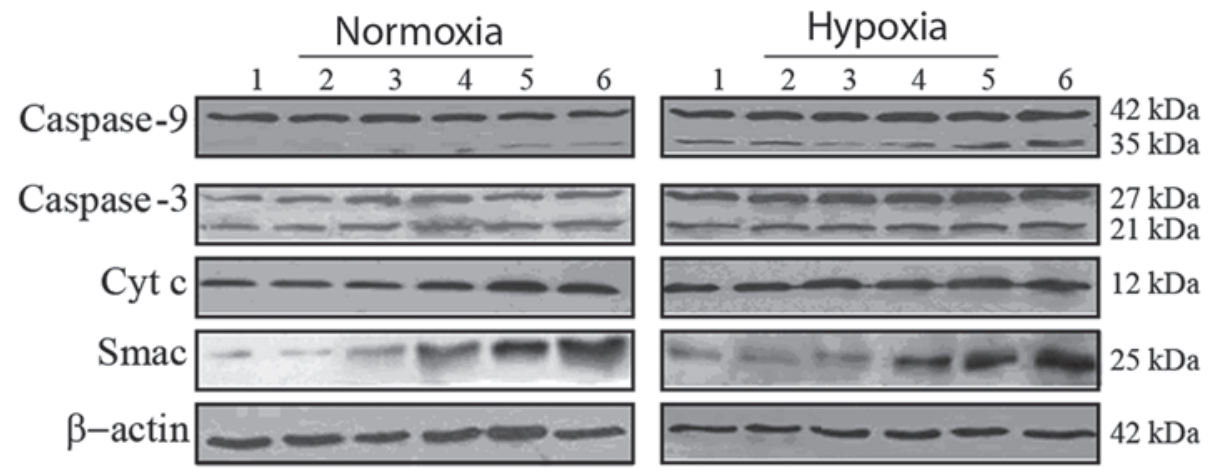

Figure 4. Protein expression of Smac, Cyt c, caspase-9 and -3 in A549 cells, as determined using western blot analysis. Lane 1, control; lane 2, pE-Smac; lane 3, pH/E-Smac; lane 4, 2 Gy; lane 5, pE-Smac+2 Gy; lane 6, pH/E-Smac+2 Gy. pE-Smac, pcDNA3.1-Egr1-Smac; pH/E-Smac, pcDNA3.1-HRE/Egr1-Smac; Cyt c, cytochrome $c$; Smac, second mitochondria-derived activator of caspases.

and regulated by ionizing radiation in a temporal and spatial dose-dependent manner $(6,8,25)$, was used to enhance the expression of the Smac gene. The present study combined the HRE and Egr-1 promoters, forming a dual-sensitive chimeric HRE/Egr-1 promoter to induce the expression of the pro-apoptotic Smac gene in A549 human lung adenocarcinoma cells subjected to hypoxia and X-ray irradiation. The results showed that 2 Gy X-ray radiation alone was capable of inducing the
Egr-1 promoter to enhance the expression of Smac. The HRE promoter is inactive under normoxia. Under hypoxia, 2 Gy $\mathrm{X}$-ray radiation was observed to markedly enhance Smac expression in A549 cells. Therefore, the radiation-induced Egr-1 promoter and the hypoxia-induced HRE promoter may synergize to improve the efficacy of radiotherapy.

The overexpression of Smac has been reported to promote tumor cell apoptosis through the mitochondrial pathway 
and enhance the sensitivity of tumor cells to radio- and chemotherapy (26-32). The present study found that the overexpression of Smac in A549 cells under normoxia enhanced $\mathrm{X}$-ray radiation-induced $\mathrm{G}_{2} / \mathrm{M}$ arrest and apoptosis, and increased the protein and mRNA expression of Cyt $c$, and caspase- 9 and -3 . These findings indicate that Smac overexpression is capable of inducing A549 cell apoptosis by activating caspase- 9 and -3 and increasing Cyt $c$, suggesting that the Cyt $c /$ caspase-9/caspase-3 pathway is involved in the regulation of apoptosis.

In accordance with a study by Zeng et al (33), $\mathrm{CoCl}_{2}$-simulated hypoxia in the present study was observed to induce $G_{0} / G_{1}$ arrest. $G_{0} / G_{1}$ arrest renders cells sensitive to radiation, which enhances the efficacy of radiotherapy (34). Hypoxia-induced $G_{0} / G_{1}$ arrest also enhances radiation-induced apoptosis without radiation resistance. In the present study, the HRE/Egr-1 promoter was found to mediate the overexpression of Smac, leading to enhanced $\mathrm{G}_{2} / \mathrm{M}$ arrest in A549 cells. $\mathrm{G}_{2} / \mathrm{M}$ arrest also renders cells sensitive to radiation. In this study, compared with cells under normoxia, hypoxic cells were observed to exhibit enhanced apoptosis, $\mathrm{G}_{2} / \mathrm{M}$ arrest and expression of Cyt $c$, as well as caspase- 9 and -3 . These findings indicate that the constructed hypoxia/radiation dual-sensitive chimeric HRE/Egr-1 promoter has a role in gene therapy under hypoxia.

In conclusion, the hypoxia/radiation dual-sensitive HRE/Egr-1 promoter-mediated Smac overexpression vector was successfully constructed in the present study. Following transfection of A549 human lung adenocarcinoma cells, radiation and hypoxia were observed to induce the overexpression of Smac, leading to proliferation inhibition, enhanced apoptosis and $\mathrm{G}_{2} / \mathrm{M}$-phase arrest. Furthermore, cell apoptosis was found to involve the mitochondrial Cyt $c /$ caspase-9/caspase-3 pathway. HRE/Egr-1 promoter-mediated gene-radiotherapy achieved enhanced efficacy and synergized radiotherapy and gene therapy, providing an experimental basis for gene-radiotherapy in lung cancer.

\section{References}

1. Kwong DL, Sham JS, Leung LH, Cheng AC, Ng WM, Kwong PW, Lui WM, Yau CC, Wu PM, Wei W and Au G: Preliminary results of radiation dose escalation for locally advanced nasopharyngeal carcinoma. Int J Radiat Oncol Biol Phys 64: 374-381, 2006

2. Zheng AQ, Song XR, Yu JM, Wei L and Wang XW: Liposome transfected to plasmid-encoding endostatin gene combined with radiotherapy inhibits liver cancer growth in nude mice. World $\mathrm{J}$ Gastroenterol 11: 4439-4442, 2005.

3. Harari PM and Huang SM: Head and neck cancer as a clinical model for molecular targeting of therapy: combining EGFR blockade with radiation. Int J Radiat Oncol Biol Phys 49: 427-433, 2001

4. Weichselbaum RR and Kufe D: Translation of the radio- and chemo-inducible TNFerade vector to the treatment of human cancers. Cancer Gene Ther 16: 609-619, 2009.

5. Kufe D and Weichselbaum R: Radiation therapy: activation for gene transcription and the development of genetic radiotherapy-therapeutic strategies in oncology. Cancer Biol Ther 2: 326-329, 2003.

6. Liu LL, Smith MJ, Sun BS, Wang GJ, Redmond HP and Wang JH: Combined IFN-gamma-endostatin gene therapy and radiotherapy attenuates primary breast tumor growth and lung metastases via enhanced CTL and NK cell activation and attenuated tumor angiogenesis in a murine model. Ann Surg Oncol 16: 1403-1411, 2009.
7. Yang W and Li XY: Anti-tumor effect of pEgr-interferon-gam ma-endostatin gene-radiotherapy in mice bearing Lewis lung carcinoma and its mechanism. Chin Med J (Engl) 118: 296-301, 2005.

8. Li Y, Guo C, Wang Z, Gong P, Sun Z and Gong S: Enhanced effects of TRAIL-endostatin-based double-gene-radiotherapy on suppressing growth, promoting apoptosis and inducing cell cycle arrest in vascular endothelial cells. J Huazhong Univ Sci Technolog Med Sci 32: 167-172, 2012.

9. Toma-Daşu I, Daşu A and Karlsson M: The relationship between temporal variation of hypoxia, polarographic measurements and predictions of tumor response to radiation Phys Med Biol 49: 4463-4475, 2004.

10. Lok CN and Ponka P: Identification of a hypoxia response element in the transferrin receptor gene. J Biol Chem 274: 24147-24152, 1999.

11. Okino ST, Chichester CH and Whitlock JP Jr: Hypoxia-inducible mammalian gene expression analyzed in vivo at a TATA-driven promoter and at an initiator-driven promoter. J Biol Chem 273: 23837-23843, 1998.

12. Kwon OJ, Kim PH, Huyn S, Wu L, Kim M and Yun CO: A hypoxia-and \{alpha\}-fetoprotein-dependent oncolytic adenovirus exhibits specific killing of hepatocellular carcinomas. Clin Cancer Res 16: 6071-6082, 2010

13. Leskov KS, Criswell T, Antonio S, Li J, Yang CR, Kinsella TJ and Boothman DA: When X-ray-inducible proteins meet DNA double strand break repair. Semin Radiat Oncol 11: 352-372, 2001.

14. Wang WD, Chen ZT, Li DZ, Duan YZ, Wang ZX and Cao ZH: HSV-TK gene therapy of lung adenocarcinoma xenografts using a hypoxia/radiation dual-sensitive promoter. Ai Zheng 23 : 788-793, 2004 (In Chinese)

15. Wu G, Chai J, Suber TL, Wu JW, Du C, Wang X and Shi Y: Structural basis of IAP recognition by Smac/DIABLO. Nature 408: 1008-1012, 2000.

16. Mühlethaler-Mottet A, Bourloud KB, Auderset K, Joseph JM and Gross N: Drug-mediated sensitization to TRAIL-induced apoptosis in caspase-8-complemented neuroblastoma cells proceeds via activation of intrinsic and extrinsic pathways and caspase-dependent cleavage of XIAP, Bcl-xL and RIP. Oncogene 23: 5415-5425, 2004.

17. McNeish IA, Bell S, McKay T, Tenev T, Marani M and Lemoine NR: Expression of Smac/DABLO in ovarian carcinoma cells induces apoptosis via a caspase-9 mediated pathway. Exp Cell Res 286: 186-198, 2008.

18. Du N, Yang B, Hu LJ, Zhao Y, Sun X, Guo ZW and Ren H: Overexpression of Smac gene enhanced chemotherapeutic sensitivity of esophageal cancer cell line Eca109 to cisplatin. Xi Bao Yu Fen Zi Mian Yi Xue Za Zhi 28: 344-346, 2012 (In Chinese).

19. Guo C, Li Y, Zhang H, et al: Enhancement of antiproliferative and proapoptotic effects of cadmium chloride combined with hSmac in hepatocellular carcinoma cells. Chemotherapy 57: 27-34, 2011

20. Dai M, Cui P, Yu M, Han J, Li H and Xiu R: Melatonin modulates the expression of VEGF and HIF-1 alpha induced by $\mathrm{CoCl}_{2}$ in cultured cancer cells. J Pineal Res 44: 121-126, 2008.

21. Liu G, Gong P, Zhao H, Wang Z, Gong S and Cai L: Effect of low-level radiation on the death of male germ cells. Radiat Res 165: 379-389, 2006

22. United Nations Scientific Committee on the Effects of Atomic Radiation: 1986 Report to the General Assembly, with annexes. General Assembly Official Records: Forty-first session, Supplement No. 16 (A/41/16). United Nations, New York, NY, 1986.

23. Koressaar T and Remm M: Enhancements and modifications of primer design program Primer3. Bioinformatics 23: 1289-1291, 2007.

24. Harada $\mathrm{H}$ : How can we overcome tumor hypoxia in radiation therapy? J Radiat Res 52: 545-556, 2011.

25. Min FL, Zhang $\mathrm{H}$ and $\mathrm{Li} \mathrm{WJ}$ : Current status of tumor radiogenic therapy. World J Gastroenterol 11: 3014-3019, 2005.

26. Mizutani Y, Nakanishi H, Yamamoto K, Li YN, Matsubara H, Mikami K, Okihara K, Kawauchi A, Bonavida B and Miki T: Downregulation of Smac/DIABLO expression in renal cell carcinoma and its prognostic significance. J Clin Oncol 23: 448-454, 2005

27. Pluta P, Cebula-Obrzut B, Ehemann V, et al: Correlation of Smac/DIABLO protein expression with the clinico-pathological features of breast cancer patients. Neoplasma 58: 430-435, 2011 
28. Fulda S, Wick W, Weller M and Debatin KM: Smac agonists sensitize for Apo-2L/TRAIL or anticancer drug-induced apoptosis and induce regression of malignant glioma in vivo. Nat Med 8: 808-815, 2002.

29. Fulda $S$ and Vucic D: Targeting IAP proteins for therapeutic intervention in cancer. Nat Rev Drug Discov 11: 109-124, 2012.

30. Le Bras M, Rouy I and Brenner C: The modulation of inter-organelle cross-talk to control apoptosis. Med Chem 2: 1-12, 2006.

31. Flanagan L, Sebastià J, Tuffy LP, Spring A, Lichawska A, Devocelle M, Prehn JH and Rehm M: XIAP impairs Smac release from the mitochondria during apoptosis. Cell Death Dis 1: e49, 2010
32. Zhou LL, Zhou LY, Luo KQ and Chang DC: Smac/DIABLO and cytochrome $c$ are released from mitochondria through a similar mechanism during UV-induced apoptosis. Apoptosis 10: 289-99, 2005.

33. Zeng HL, Zhong Q, Qin YL, Bu QQ, Han XA, Jia HT and Liu HW: Hypoxia-mimetic agents inhibit proliferation and alter the morphology of human umbilical cord-derived mesenchymal stem cells. BMC Cell Biol 12: 32, 2011.

34. Huang SM and Harari PM: Modulation of radiation response after epidermal growth factor receptor blockade in squamous cell carcinomas: inhibition of damage repair, cell cycle kinetics, and tumor angiogenesis. Clin Cancer Res 6: 2166-2174, 2000. 